\title{
ANALISIS KEMAMPUAN BERPIKIR KRITIS DALAM KETERAMPILAN MENULIS KARANGAN EKSPOSISI DI KELAS V SDN CIREWED, KABUPATEN TANGERANG
}

\author{
Novi Dama Yanti', Dilla Fadhillah ${ }^{2}$, Enawar ${ }^{3}$, Sumiyani $^{4}$ \\ Universitas Muhammadiyah Tangerang, Kota Tangerang \\ nesyanovi86@gmail.com, dillafadhillah89@gmail.com, enawar.abah@ gmail.com, \\ sumiyaninitura@gmail.com
}

\begin{abstract}
ABSTRAK
Kemampuan berpikir kritis dalam keterampilan menulis karangan eksposisi menjadi hambatan masuknya informasi kepada siswa. Penelitian ini bertujuan untuk mengetahui apa saja bentuk kemampuan berpikir kritis dalam keterampilan menulis karangan eksposisi dikelas V SDN Cirewed Kabupaten Tangerang dan untuk mengetahui apa saja faktor penyebab kemampuan berpikir kritis dalam keterampilan menulis karangan eksposisi dikelas V SDN Cirewed Kabupaten Tangerang. Metode yang digunakan dalam penelitian ini adalah kualitatif deskriptif dengan menggunakan teknik pengumpulan data berupa tes, wawancara, observasi dan dokumentasi. Pemeriksaan keabsahan data menggunakan triangulasi. Data dianalisis melalui langkah-langkah pengumpulan data, reduksi data, penyajian data, dan menarik kesimpulan. Responden pada penelitian ini berjumlah 12 orang yakni Guru kelas V, dan 25 siswa kelas V. Berdasarkan hasil penelitian bahwa Analisis Kemampuan Berpikir Kritis dalam Keterampilan Menulis Karangan Eksposisi dikelas V SDN Cirewed Kab.Tangerang. Dalam keterampilan menulis karangan eksposisi seharusnya sudah sering dilakukan oleh siswa kelas $\mathrm{V}$ untuk mempermudah mereka pada saat proses pembelajaran di sekolah. Faktor-faktor yang mempengaruhi kemampuan berpikir kritis dalam keterampilan menulis karangan eksposisi dikelas $\mathrm{V}$ yaitu berasal dari faktor internal yang meliputi tentang mengenal masalah dalam menentukan tema, menemukan cara-cara yang dapat dipakai untuk menangani masalah dalam menentukan tujuan, mengumpulkan dan menyusun data informasi yang sesuai dengan tema, dapat memahami dan menggunakan bahasa yang tepat dan jelas untuk membuat kerangka karangan, menyusun kembali pola-pola keyakinan berdasarkan pengalaman yang luas dalam mengembangkan kerangka karangan menjadi karangan eksposisi, menganalisis data dan mengevaluasi, dan membuat kesimpulan. Selain itu, kesulitan yang di alami siswa yaitu siswa tidak mampu mengumpulkan dan menyusun data informasi yang sesuai dengan tema, kemampuan untuk mengumpulkan data yang sesuai dengan tema siswa masih kebinggungan, dan masih ada beberapa siswa yang benar-benar sama sekali belum paham, namun ada juga beberapa siswa yang sudah mengerti. Adapun poin penilaian dalam kemampuan berpikir kritis pada aspek pertama yaitu $9 \%$, poin ke dua $15 \%$, poin ke tiga $16 \%$, poin ke empat $19 \%$, poin ke lima $10 \%$, poin ke enam $11 \%$, dan poin ke tujuh $20 \%$.
\end{abstract}

Kata Kunci: Analisis, Kemampuan Berpikir Kritis, Keterampilan Menulis, Karangan Eksposisi.

\begin{abstract}
The ability to think critically in the skill of writing an expository essay is a barrier to the entry of information to students. This study aims to find out what forms of critical thinking skills are in writing exposition essay skills in class V SDN Cirewed Tangerang Regency and to find out what are the factors causing critical thinking skills in writing exposition essay writing skills in class V SDN Cirewed Tangerang Regency. The method used in this research is descriptive qualitative using data collection techniques in the form of tests, interviews, observation, and documentation. Check the validity of the data using triangulation. The data were analyzed through the steps of data collection, data reduction, data presentation, and drawing conclusions. Respondents in this study amounted to 12 people, namely class V teachers, and 25 students in
\end{abstract}




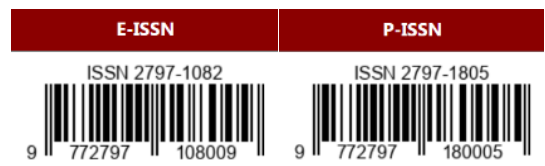

class V. Based on the results of the study that Analysis of Critical Thinking Skills in Writing Exposition Writing Skills in class V SDN Cirewed Kab.Tangerang. In the skill of writing exposition essays, fifth grade students should often do it to make it easier for them during the learning process at school. Factors that influence critical thinking skills in writing expository essay writing skills in class $V$ are derived from internal factors which include recognizing problems in determining themes, finding ways that can be used to deal with problems in determining goals, collecting, and compiling appropriate information data. with a theme, able to understand and use precise and clear language to outline an essay, rearrange belief patterns based on extensive experience in developing an outline into an expository essay, analyze data and evaluate, and draw conclusions. In addition, the difficulties experienced by students are that students are not able to collect and compile information data that is in accordance with the theme, the ability to collect data that is in accordance with the theme of students is still confused, and there are still some students who really do not understand at all, but there are also some students who already understand. The assessment points in critical thinking skills in the first aspect are 9\%, the second point is 15\%, the third point is 16\%, the fourth point is 19\%, the fifth point is 10\%, the sixth point is $11 \%$, and the seventh point is $20 \%$.

Keywords: Analysis, Critical Thinking Skills, Writing Skills, Expository Writing.

\section{PENDAHULUAN}

Pendidikan merupakan suatu pembelajaran pengetahuan, keterampilan, dan kebiasaan sekelompok orang yang diturunkan dari generasi ke generasi berikutnya melalui pengajaran, pelatihan atau penelitian. Pendidikan sering terjadi dibawah bimbingan orang lain, tetapi juga memungkinkan secara otodidak.

Pendidikan juga memiliki fungsi di antaranya adalah proses untuk meningkatkan kecerdasan siswa, memperbaiki, mengubah pengetahuan, keterampilan, dan sikap serta tingkah laku seseorang atu sekelompok dalam usaha mencerdasakan kehidupan manusia melalui kegiatan pengajaran dan pelatihan,mengembangkan kemampuan serta keterampilan yang dimiliki oleh siswa, membentuk watak atau karakter siswa,kepribadian agar peserta didik dapat menjadi pribadi yang lebih baik, membangun serta mengembangkan minat bakat individu,suatu usaha yang dilakukan secara sadar dan sengaja dengan melibatkan siswa secara aktif mengembangkan potensi yang dimiliki, mengubah sikap, dan tingkah laku menuju kedewasaan melalui upaya pengajaran dan latihan. Sesuai dengan UU
No. 20 Tahun 2003, tentang system Pendidikan Nasional, pendidikan berfungsi untuk mengembangkan kemampuan dan membentuk watak serta peradaban bangsa yang bermatabat dalam rangka mencerdaskan kehidupan bangsa.

Seiring dengan perkembangan zaman pendidikan juga perlu dikembangkan secara luas. Supaya siswa dapat menambah wawasan serta dapat menambah pengetahuan yang sebelumnya belum paham menjadi lebih paham dan mudah dimengerti. Dalam hal ini kelas diperlukan pengembangan dalam sebuah pembelajaran yang digunakan guru dalam proses $\mathrm{kbm}$ berlangsung atau pada saat proses pembelajaran berlangsung dikelas. Sehingga pembelajaran tidak hanya diartikan dengan mentranfer ilmu oleh guru untuk siswanya. Dalam pendidikan terdapat beberapa jalur terdiri dari pendidikan formal dan non formal. Pada jenjang pendidikan formal terdiri dari sekolah dasar sampai ke perguruan tinggi.

Pendidikan Sekolah Dasar merupakan pendidikan yang jenjang paling dasar pada pendidikan formal di Indonesia. Sekolah dasar ditempuh dalam waktu 6 tahun, mulai dari kelas 1 sampai kelas 6. Dan umurnya dimulai 
dari umur 7 tahun sampai 13 tahun. Saat ini murid kelas 6 diwajibkan untuk mengikuti Ujian Nasional (UN) yang dapat mempengaruhi kelulusan siswa. Lulusan sekolah dasar dapat melanjutkan ke tingkat SMP.

Di Sekolah Dasar pada saat ini sudah memakai K13, kurikulum ini merupakan kurikulum tetap yang ditetapkan pemerintah untuk menggantikan Kurikulum 2006. Sehingga di kulikulum k13 ada beberapa mata pelajaran yang diajarkan seperti: IPA, Matematika, Bahasa Inggris, IPS, Penjaskes atau olahraga, PPKN, IPS, Seni Rupa dan Budaya. Salah satunya yakni mata pelajaran Bahasa Indonesia.

Pengajaran dalam pembelajaran bahasa Indonesia merupakan salah satu materi pelajaran yang sangat penting di sekolah. Tujuan pembelajaran bahasa Indonesia adalah agar siswa memiliki kemampuan berbahasa Indonesia dengan baik dan benar serta menghayati bahasa Indonesia sesuai dengan situasi dan tujuan berbahasa serta tingkat pengalaman siswa sekolah dasar, dan untuk mengembangkan kemampuan berbahasa Indonesia sesuia kemampuan, kebutuhan, dan minat bakatnya

Pembelajaran bahasa Indonesia di sekolah di harapkan dapat membantu siswa mengenal dirinya, budayanya dan budaya orang lain, mengemukakan gagasan dan perasaan, berpartisipasi dalam masyarakat yang menggunakan bahasa tersebut dan menemukan serta menggunakan kemampuan analisis dan imajinatif yang ada dalam dirinya. Pembelajaran bahasa Indonesia juga diarahkan untuk mengingkatkan kemampuan peserta didik untuk berkomunikasi dalam bahasa Indonesia dengan baik dan benar, baik secara lisan maupun tulisan, serta menumbu. Pembelajaran bahasa Indonesia juga diarahkan untuk mengingkatkan kemampuan peserta didik untuk berkomunikasi dalam bahasa Indonesia dengan baik dan benar, baik secara lisan maupun tulisan, serta menumbuhkan apresiasi terhadap hasil karya. Aspek kemampuan berbahasa meliputi keterampilan menyimak, keterampilan berbicara, keterampilan membaca dan keterampilan menulis.

Keterampilan menulis merupakan salah satu aspek keterampilan berbahasa yang harus dikuasai siswa, selain ketiga keterampilan lain yaitu membaca, menyimak dan berbicara. Pembelajaran menulis di sekolah dasar diberikan melalui mata pelajaran Bahasa Indonesia. Meskipun pembelajaran menulis telah disadari merupakan bagian penting dalam pembelajaran bahasa Indonesia di sekolah dasar, namun pada kenyataannya pembelajaran menulis kurang mendapat perhatian dari guru maupun siswa. Pembelajaran menulis atau mengarang kurang ditangani secara sungguh-sungguh, sehingga keterampilan menulis yang dimiliki siswa kurang memadai. Keterampilan menulis sangat penting untuk dikuasai peserta didik, dan banyak memberikan manfaat dalam kehidupan yang serba maju sekarang ini.

Menulis merupakan suatu kegiatan yang penting untuk dapat menuangkan isi pikiran, gagasan atau pendapat, ide maupun perasaan seseorang. Pada pembelajaran menulis di sekolah dasar kelas tinggi, standar kompetensi yang tercantum dalam KTSP adalah mengungkapkan pendapat dan perasaan ke dalam bentuk tulisan baik karangan, pantun maupun puisi. Tentu saja menuangkan pendapat dan perasaan dalam bentuk karangan (mengarang) memerlukan konsentrasi dan daya kreatif yang tinggi dalam memilih kata dan pengorganisasian kalimat. Namun perlu disadari pula bahwa 
siswa sekolah dasar tentu mengalami proses belajar menulis karangan dari karangan yang sederhana menuju yang lebih komplek sesuai dengan perkembangan kognitifnya.

Kemampuan menulis didapatkan bukan melalui warisan, tetapi didapatkan melalui proses belajar mengajar. Keterampilan menulis karangan dapat dimiliki oleh semua siswa jika mereka mendapat bimbingan dan latihan menulis secara intensif. Selain itu, peran guru juga sangat penting dalam melatih dan membimbing siswa menulis karangan dengan baik. Perbaikan dan umpan balik dari guru juga sangat diperlukan agar setiap kesalahan maupun kesulitan yang dihadapi siswa dapat diatasi, sehingga keterampilan menulis karangan siswa dapat meningkat. Seorang guru seharusnya mampu merangsang daya pikir dan kreatifitas peserta didik dalam mengekspresikan perasaan dan pendapatnya baik secara lisan maupun tertulis.

Keterampilan menulis karangan harus diajarkan dalam bentuk aktivitas pembelajaran yang bermakna dan menarik bagi siswa. Selain itu, juga dapat dioptimalkan dengan peran guru yang mampu menciptakan suatu lingkungan belajar yang kondusif. Guru harus bisa memahami kesulitan yang dihadapi siswa ketika menulis sebuah karangan. Guru yang memahami kesulitan siswa dalam menulis karangan akan memberikan pengertian bahwa menulis tidak harus sekali jadi. Kekurangan maupun kesalahan adalah sebuah proses belajar. Pembelajaran menulis karangan menuntut kerja keras guru untuk membuat pembelajaran yang menyenangkan sehingga siswa tidak merasa dipaksa untuk membuat tulisan atau karangan, tetapi sebaliknya siswa merasa senang hatinya untuk menulis sebagai media menuangkan ekspresinya. Karena dalam menulis memerlukan keterlibatan dalam proses berpikir kritis. Agar siswa dikatakan terampil dalam menulis, maka diperlukan ide-ide yang dibisa dituangkan dalam sebuah bentuk karangan.

Berdasarkan hasil wawancara guru wali kelas V di salah satu SDN Cirewed Kecamatan Cikupa Kabupaten Tangerang yaitu, kegiatan menulis kurang diminati siswa, sehingga mereka mengalami kesulitan dalam mengungkapkan atau menuangkan ideide pikiran dan gagasan pokok pada saat menulis karangan eksposisi. Dan rendahnya dalam penguasaan kosa kata siswa disebabkan karena rendahnya minat membaca siswa, kurangnya penguasaan tanda baca, serta kurangnya penyusunan paragraf. Hal tersebut disebabkan karena malasnya siswa untuk belajar, sehingga untuk membangun pengetahuan yang baru dan pengalamannya sesuai materi pembelajaran masih rendah. Siswa sulit mengkomunikasikan pengetahuannya kedalam bentuk tulisan. Hal tersebut disebabkan kurangnya minat siswa untuk menulis karena siswa beranggapan menulis merupakan pekerjaan yang membosankan. Siswa kesulitan mengembangkan ide atau gagasan dan memahami ciri-ciri karangan eksposisi. Hal tersebut disebabkan karena kebiasaan membaca siswa masih sangat rendah, kurangnya pengetahuan, dan kurangnya pemahaman siswa dalam memahami karangan eksposisi. Akibatnya banyak siswa yang memperoleh nilai yang dibawah ratarata.

Alasan peneliti mengambil permasalahan yang terjadi di SDN Cirewed Kecamatan Cikupa Kabupaten Tangerang, karena pada mata pelajaran bahasa indonesia yang kurang di minati siswa dalam menulis, dan kesulitannya siswa untuk mengembangkan ide atau gagasan pokok dan 
memahami ciri-ciri karangan eksposisi, serta kurangnya pemahaman dalam mengkomunikasikan pengetahuannya dalam bentuk tulisan, dan kurangnya siswa untuk mengemukakan pendapatnya. Hal ini menyebabkan siswa kurang termotivasi dalam mengikuti pelajaran bahasa Indonesia, sedangkan dalam kemampuan menulis karangan sangat penting dimengerti siswa karena dengan menulis karangan eksposisi siswa dapat berpikir kritis, dapat memperluas berkomunikasi dan mampu menangkap pengetahuan lebih dalam. Banyak hal yang harus diperhatikan dalam menulis yaitu pengunaan tanda baca, pemilihan kata dan kalimat, dan pembuatan paragraf.

Dalam proses pembelajaran menulis karangan eksposisi, telah ditemukan beberapa kesalahan. Ada kesesalahan yang sering muncul pada saat penulisan karangan eksposisi siswa, yang terletak pada kurangnya pemahaman dalam mengkomunikasikan pengetahuannya dalam bentuk tulisan, kurangnya pengunaan kosa kata, kurangnya pemilihan kata dan kalimat. dan kuragnya ideide atau gagasan pokok yang belum berkembang. Maka dari itu dalam menulis karangan eksposisi dibutuhkan sebuah pemikiran yang luas karena kita tulis adalah ide-ide pokok atau gagasan. Disamping itu siswa juga perlu mengembangkan ide-ide yang kritis, bukan hanya sekedar mengarang. Oleh karena itu maka siswa membutuhkan pemikiran-pemikiran yang lebih luas dengan mengembangkan kemampuannya untuk berpikir kritis untuk menuangkan ide-ide atau gagasan pokok dan menuangkan pendapatnya. Berdasarkan kondisi yang terjadi, maka penulis sangat tertarik untuk meneliti masalah yang berjudul "Analisis Kemampuan Berpikir Kritis Dalam Keterampilan Menulis Karangan Eksposisi Di
Kelas V SDN Cirewed Kabupaten Tangerang.“

\section{LANDASAN TEORI}

Menurut Fisher (2016) "Berpikir kritis adalah sebagai pertimbangan yang aktif yang dilakukan secara terus-menerus, dan teliti mengenai sebuah keyakinan atau bentuk pengetahuan yang diterima begitu saja di pandang dari sudut alasan-alasan yang mendukungnya dan kesimpulankesimpulan lanjutan yang menjadi kecenderungan" (h.2). Berpikir kritis sebagai proses yang dilakukan secara terus-menerus dan teliti, dengan cara berpikir yang tidak di refleksikan di mana kita kadang-kadang menggunakannya misalnya ketika kita buru-buru menuju kesimpulan atau membuat suatu keputusan yang cepat tanpa memikirkannya.

Menurut Chatfield (2020) "Berpikir kritis adalah suatu sikap berpikir secara mendalam tentang masalah-masalah dan halhal yang berada dalam jangkauan pengalaman seseorang, serta pengetahuan tentang metodemetode pemeriksaan dan pemahaman yang logis dan semacam suatu keterampilan untuk menerapkan metode-metode tersebut. Berpikir kritis menuntut upaya keras untuk memeriksa setiap pengetahuan berdasarkan pendukungnya dan kesimpulan-kesimpulan lanjutan yang diakibatkannya" (h.3). Selain itu juga berpikir kritis`memiliki rasa keingintahuan yang sangat tinggi terhadap informasi-informasi yang didapatkannya dan selalu mencari informasi dan bukti terbaru. Orang yang memiliki pemikiran secara kritis berpikiran terbuka tidak ada yang ditutuptutupi atau tidak gengsi mengakui kesalahan atau kekurangannya saat dihadapkan pada bukti yang meyakinkan bahwasanya ternyata ide dan pendapatnya salah. 
Menurut Zakiah (2019), Berpikir kritis juga memiliki beberapa ciri-ciri menyebutkan sebagai berikut:

a. Mengenal secara rinci bagian-bagian dari keputusan.

b. Pandai mendeteksi permasalah.

c. Mampu membedakan ide yang relevan dengan ide yang tidak relevan.

d. Mampu membedakan fakta dengan pendapat.

e. Dapat membedakan antara kritik yang membangun dan merusak.

f. Mampu mengidentifikasi atribut-atribut manusia, tempat, dan benda, seperti dalam sifat, bentuk, wujud.

g. Mampu mendaftarkan segala akibat yang mungkin terjadi atau terhadap pemecahan masalah, ide, dan situasi.

h. Mampu membuat hubungan yang berurutan antara satu masalah dengan masalah yang lainnya.

i. Menarik kesimpulan dari data yang telah tersedia.

j. Mampu membuat prediksi dari informasi yang tersedia.

k. Dapat membedakan konlusi salah dan tepat terhadap informasi yang diterima.

1. Membuat kesimpulan dari data yang telah ada dan terseleksi.

Menurut Fadhillah (2019) "Karangan Eksposisi adalah karangan yang memuat secara rinci sebuah tahapan-tahapan mengenai sesuatu. Langkah-langkah dijelaskan secara urut dalam karangan ini. Banyak yang menyimpulkan bahwa karangan eksposisi ini adalah karangan proses" (h.98). Karangan eksposisi juga berisi tentang paparan pikiran dan pendapat-pendapat pemikiran seseorang, dapat memperluasan wawasan dalam ilmu pengetahuan.
Menurut Dalman (2020), terdapat tiga jenis karangan eksposisi dengan pemaparan berikut ini:

a. Lukisan dalam eksposisi

Yang dimaksud lukisan dalam eksposisi ini adalah paparan yang mempergunakan lukisan, supaya karangan paparan itu tidak kering. Contohnya: otobiografi, kisah perampokan dan kecelakaan.

b. Eksposisi Proses

Eksposisi yang memaparkan atau menjelaskan proses terjadinya sesuatu. Misalnya: proses pembuatan tempe, proses pembuatan nasi goreng, proses pembuatan jamur merang, proses berdirinya organisasi.

c. Eksposisi perbandingan

Dalam memperjelas paparan yang sering digunakan perbandingan di antara dua atau lebih hal. Kedua hal atau lebih itu dicari perbedaan dan persamaannya (h.101).

Menurut Jultia (2019), mengemukakan bahwa teks eksposisi memiliki tiga struktur sebagai berikut: (a) tesis atau pernyataan pendapat, (b) rangkaian argument, dan (c) penegasan ulang.

\section{METODE PENELITIAN}

Dalam penelitian ini menggunakan pendekatan penelitian kualitatif, dalam penelitian. ini menggunakan jenis metode kualitatif deskriptif. Penelitian ini dilaksanakan dengan berdasarkan kejadian yang terjadi di lapangan. Agar peneliti dapat mendeskripsikan secara detail, jelas dan terperinci serta mendapatkan data yang mendalam mengenai "Analisis kemampuan berpikir kritis dalam keterampilan menulis karangan eksposisi dikelas V SDN Cirewed Kabupaten Tangerang." Hal yang sangat diutamakan dalam penelitian kualitatif yaitu dapat mengungkapkan suatu data dan 
informasi yang dapat ditarik makna dan konsepnya.

Menurut Mawardi (2019), "Penelitian kualitatif adalah penelitian yang menggunakan lingkungan alamiah sebagai sumber data. Penelitian kualitatif sifatnya deskriptif analitik. Data yang diperoleh seperti hasil pengamatan, hasil wawancara, hasil analisis dokumen, catatan lapangan, dan tidak dituangkan dalam bentuk angka-angka" (h.18). Penelitian ini dilakukan pada objek yang alamiah, ojek yang dapat berkembang dengan apa adanya, tidak dimanipulasi oleh peneliti, dan kehadiran peneliti tidak mempengaruhi dinamika pada objek tersebut. Untuk dapat menjadi sebuat instrument, maka peneliti harus memiliki bekal teori dan wawancara yang luas sehingga mampu bertanya, menganalisis, memotret, dan mengkonstruksi situasi social yang diteliti menjadi lebih jelas dan bemakna. Tujuan dari penelitian ini yaitu untuk mengetahui kemampuan berpikir kritis dalam keterampilan menulis karangan eksposisi dikelas V SDN Cirewed Kabupaten Tangerang. Data dalam penelitian ini diperoleh dengan menggunakan instrument penelitian berupa wawancara, observasi, Tes, dan dokumentasi.

Teknik pengumpulan data sebagai langkah paling utama dalam penelitian karena tujuan utama dalam penelitian. Karena tujuan utama pengumpulan data adalah mendapatkan data dari sumber data.Karena tanpa menggunakan teknik pengumpulan data peneliti tidak dapat menemukan data yang standar yang sudah ditetapkan. Teknik pengumpulan data dapat dilakukan dalam berbagai sumber dan cara seperti tes, wawancara, observasi dan dokumentasi.

\section{HASIL DAN PEMBAHASAN}

Penelitian ini dimaksud untuk mengetahui kemampuan berpikir kritis dalam menulis karangan eksposisi dari hasil penelitian yang peneliti lakukan yaitu terdapat 12 siswa yang mendapatkan penilaian dibawah rata-rata dari 25 siswa keseluruhan di SD tersebut.

Berdasarkan hasil tes dan observasi yang telah dilaksanakan oleh peneliti. Selain dari tes dan observasi, pertimbangan dari guru mengenai siswa yang mengalami kesulitan adapun beberapa faktornya yaitu belum bisa merangkai sebuah kalimat dengan jelas, dan penggunaan huruf kapital. Padahal dalam pelaksaan tes berlangsung, siswa di minta untuk mengerjakan soal sesuai kemampuannya, dalam kemampuan berpikir kritis mengenai menulis karangan eksposisi. Tes yang dilaksanakan dalam rentang waktu 1 x 30 menit atau 1 Jam pelajaran. Kegiatan ini berlangsung dengan baik. Setelah selesai mengerjakan soal tes, peneliti mencermati hasil pekerjaan siswa. Adapun poin penilaian dalam kemampuan berpikir kritis dalam keterampilan menulis karangan eksposisi pada aspek pertama yaitu $9 \%$, poin ke dua $15 \%$, poin ke tiga $16 \%$, poin ke empat $19 \%$, poin ke lima $10 \%$, poin ke enam $11 \%$, dan poin ke tujuh $20 \%$.

\section{KESIMPULAN DAN SARAN Kesimpulan}

Berdasarkan hasil penelitian tentang Analisis Kemampuan Berpikir Kritis dalam Keterampilan Menulis Karangan Eksposisi dikelas V SDN Cirewed Kab.Tangerang. Peneliti dapat menarik kesimpulan bahwa kemampuan berpikir kritis dalam keterampilan menulis karangan eksposisi seharusnya sudah sering dilakukan oleh siswa 
kelas V untuk mempermudah mereka pada saat proses pembelajaran di sekolah.

Kemampuan berpikir kritis dalam keterampilan menulis karangan eksposisi yang dilakukan oleh siswa yaitu memiliki kemampuan yang berbeda-beda, hampir keseluruhan siswa memahami mengenal masalah dalam menentukan tema yang dikerjakan pada tes berlangsung di kelas. Adapun untuk kesulitan yang di alami dari beberapa siswa yang tidak mampu memahami menggunakan bahasa yang tepat dan jelas yaitu kosa kata dan penulisan kalimat siswa masih saja menggunakan bahasa sehari-hari dan tidak baku. Sehingga kemampuan untuk menafsirkan kata dan kalimat yang benar siswa masih belum paham. Selain itu, kesulitan yang di alami siswa yaitu siswa tidak mampu mengumpulkan dan menyusun data informasi yang sesuai dengan tema, kemampuan untuk mengumpulkan data yang sesuai dengan tema siswa masih kebinggungan, dan masih ada beberapa siswa yang benar-benar sama sekali belum paham, namun ada juga beberapa siswa yang sudah mengerti. Adapun poin penilaian dalam kemampuan berpikir kritis pada aspek pertama yaitu $9 \%$, poin ke dua $15 \%$, poin ke tiga $16 \%$, poin ke empat $19 \%$, poin ke lima $10 \%$, poin ke enam $11 \%$, dan poin ke tujuh $20 \%$.

\section{Saran}

Berdasarkan kesimpulan yang telah di uraikan. Maka peneliti mempunyai beberapa saran untuk beberapa pihak yaitu:

a. Bagi guru

Diharapkan dapat memberikan pengetahuan yang menyeluruh serta nyata mengenai pentingnya kemampuan berpikir kritis dalam keterampilan menulis karangan eksposisi di sekolah dasar. b. Bagi siswa

Diharapkan kepada siswa supaya berpikir kritis dalam proses pembelajaran berlangsung dan focus dalam melakukan proses pembelajaran.

c. Bagi sekolah

Diharapkan melalui penelitian ini dapat memberikan masukan bagi kepala sekolah untuk dapat digunakan sebagai salah satu refensi dalam menerapkan cara berpikir kritis disekolah.

d. Bagi peneliti

Diharapkan dapat menambah wawasan dan pengalaman karena sesuai dengan profesi yang ditekuninya yakni calon guru sehingga nantinya bisa diterapkan dilapangan.

e. Bagi Institusi

Diharapkan dapat memberikan pembendaharaan pustaka yang berarti, seingga berguna sebagai refensi bagi pihak-pihak yang membutuhkan

\section{DAFTAR PUSTAKA}

Anggito, A. dan Setiawan, J. (2018), Metodelogi Penelitian Kualitatif, Sukabumi: CV Jejak.

Chatfield, Tom (2020), Berpikir kritis Panduan beragumen, Menganalisis dan melakukan Studi mandiri secara meyakinkan, Yogyakarta: Pustaka Belajar.

Dalman, H (2020) Keterampilan Menulis, Ed I, Cet-6, Depok: Rajawali Pers.

Fisher, Alec (2016), Berpikir kritis Sebuah Pengantar, Jakarta: Erlangga.

Fadhillah, D. Hamsanah, S.H. dan Latifah, N., (2019), Pembelajaran Bahasa Indonesia Kelas Tinggi, Yogyakarta: Samudera Biru. 
Fadhillah, D. dan Fitriani, S.H. (2018), Pembelajaran Bahasa Indonesia Kelas Rendah, Yogyakarta: Samudera Biru.

Inggriyani, F dan Fazriyah, N. "Analisis berpikir kritis terhadap kemampuan menulis narasi siswa kelas $V$ SDN Kecamatan Lengkong Kota Bandung”. JPSD.Vol.3 No.2 2017.

Jayadi, U. (2021). Penerapan Metode Pembelajaran Cooperative Integrated Reading and Composition (CIRC) Untuk Meningkatkan Hasil Belajar Dalam Menemukan Kalimat Utama Pada Siswa Kelas IV SDN 22 Mataram Tahun Pelajaran 2020/2021. Berajah Journal, $1(1)$ $21-42$.

https://doi.org/10.47353/bj.v1i1.17

Jultia, W.O. Sahlan. Dan Hanafi, F. "Kemampuan menulis teks eksposisi siswa kelas VII SMP Negeri 1 Duruka”. Jurnal Bastra.Vol.4 No.3 2019.

Latifah, N Hasan, N "Analisis keterampilan menulis eksposisi dikelas V SDN Duri Kepa Jakarta”. JPBSI.Vol 9 No.2 2020.

Mamik. (2015), Metodelogi Kualitatif, Sidoarjo: Zifatama Publisher.

Mawardi. (2019), Dasar-dasar Metodelogi Penelitian Pendidikan, Yogyakarta: Samudera Biru.

Prasetyo, B. "Kemampuan menyunting teks eksposisi siswa kelas X Ipa SMA Negeri 1 Kendari”. Jurnal Bastra.Vol.1 No.1 2016.

Siregar, A.S Sukirno dan Ramadhani, D "Analisis kemampuan berpikir kritis siswa

pada tema 8 lingkungan sahabat kita di SDN 6 Langsa Kecamatan Langsa Kota". JOBES.Vol.2 No.1 2019.

Yunus, M. (2019) Keterampilan Menulis, Ed I, Cet-11, Tangerang Selatan: Universitas Terbuka.
Zakiah, L. Lestari, I. (2019), Berpikir kritis dalam konteks pembelajaran, Bogor: Erzatama Karya Abad. 